\title{
Effect of lead and chloride ions on methane production in arable soils
}

\author{
Ewa Wnuk@, Anna Walkiewicz*® and Andrzej Bieganowski@ \\ Institute of Agrophysics, Polish Academy of Sciences, Department of Natural Environment Biogeochemistry \\ Doświadczalna 4, 20-290 Lublin, Poland
}

Received July 24, 2019; accepted February 10, 2020

\begin{abstract}
Cultivated soils in high water conditions can be a source of methane $\left(\mathrm{CH}_{4}\right)$. Despite the significant introduction of lead $(\mathrm{Pb})$ into soils with fertilizers or sewage sludge, there are few reports concerning its impact on methane production in arable soils. The main premise of the study was to characterize the response of methanogenesis after soil contamination with $\mathrm{Pb}$. For this reason, the effect of $\mathrm{Pb}$ on $\mathrm{CH}_{4}$ production in three different mineral arable soils was investigated. Lead, in the chloride form, was added at two concentrations, which were established based on the Sewage Sludge Directive (300 and $1500 \mathrm{mg} \mathrm{kg}^{-1}$ ). Additionally, two types of controls were used - water and $\mathrm{CaCl}_{2}$ with chloride ions. It was observed that the process could be slowed down at the lower dose and that methane production was totally inhibited at the higher dose. Additionally, the inhibitory effect of the chloride ions on the process was also observed in the control samples. Despite the inhibition of methanogenesis in the soil, which has a positive effect on reducing the amount of the gas released, this process cannot be analysed individually. Other reactions in the soil should also be taken into consideration, and these changes which occur under the influence of the various factors should be investigated further.
\end{abstract}

Keywords: methane, methanogenesis, arable soil, lead

\section{INTRODUCTION}

The global warming effect is a very serious problem at the present time (Fronzek et al., 2018; VijayaVenkataRaman et al., 2012). The increasing temperature of our planet is causing many human tragedies and it has global consequences such as the warming of the oceans, the melting of glaciers and the extinction of numerous animal species (Kirschke et $a l ., 2013)$. The main reason for this situation is the increasing atmospheric concentration of greenhouse gases (GHGs), including methane $\left(\mathrm{CH}_{4}\right)$. After carbon dioxide $\left(\mathrm{CO}_{2}\right)$,

*Corresponding author e-mail: a.walkiewicz@ipan.lublin.pl methane is the second GHG responsible for global warming, despite having a much lower atmospheric content than $\mathrm{CO}_{2}$. The $\mathrm{CH}_{4}$ concentration has more than doubled over the last 200 years and is now at about 1.8 ppm (Brzezińska et al., 2012; IPCC, 2014). This increase has been caused by increased emissions of methane from anthropogenic sources, such as rice production, the use of fossil fuels and the utilization of wastes, but also by an imbalance between the methane emitted and that absorbed by sinks, including soils (Contin et al., 2012; Nosalewicz et al., 2011; Stępniewska et al., 2018). Measurements carried out over the years show that the total emission of methane to the atmosphere $\left(\sim 558 \mathrm{Tg} \mathrm{year}^{-1}\right)$ is greater than the total amount of methane absorption $\left(\sim 548 \mathrm{Tg}\right.$ year $\left.^{-1}\right)$, leading to the continuous accumulation of this gas in the atmosphere (Saunois et al., 2016).

Soil is a unique environment, which can act as a $\mathrm{CH}_{4}$ sink or source, depending on the prevailing conditions. Under aerobic conditions we may observe the activity of methane-oxidizing bacteria (methanotrophs), which naturally colonize soil (Szafranek-Nakonieczna et al., 2018). These absorb $\mathrm{CH}_{4}$ from the environment and then use it as a source of the carbon and energy necessary for their survival (Bodelier and Steenbergh, 2014; Einola et al., 2007). Under anaerobic conditions, e.g., in flooded soils, the process of methane production is observed (methanogenesis). Methanogens use carbon from, e.g., methanol or formic acid to produce methane (Malyan et al., 2016; Serrano-Silva et al., 2014; Szafranek-Nakonieczna and Stępniewska, 2015). As a consequence, soil plays a crucial role in the final atmospheric $\mathrm{CH}_{4}$ concentration. The amount of methane emitted by soils accounts for approximately $40 \%$ of the

(C) 2020 Institute of Agrophysics, Polish Academy of Sciences 
total emissions of this gas (Saunois et al., 2016). The processes of $\mathrm{CH}_{4}$ production and consumption are regulated by many chemical and physical soil parameters, such as $\mathrm{pH}$, moisture, texture and nitrogen content (Majdinasab and Yuan, 2017; Tate, 2015). The common factors in arable soils are heavy metals, which may come from a parent material or may be introduced into soils via fertilizers or the sewage sludge used in agriculture (Pawłowska et al., 2011). One of the most common soil contaminants is lead $(\mathrm{Pb})$. Generally, the $\mathrm{Pb}$ concentration in soil depends on the country and varies from 18 to $27 \mathrm{mg} \mathrm{kg}^{-1}$. In addition to agricultural origins, it can also be present in the soil as a side effect of industrial activity (mining, smelting and the metal processing industry) (Kuźniar et al., 2018; Sankhla et al., 2016). The natural content is also determined by the parent rock (Kabata-Pendias, 2010).

The mobility of heavy metals in the soil and the ecological effects of their presence depends on various factors, such as $\mathrm{pH}$, temperature, particle-size distribution, waterair conditions in the soil, pore structure, fertilization or soil organic matter (Łukowski and Wiater, 2016; Sherene, 2010), and also on physicochemical processes, e.g., sorption/desorption, solution complexation, oxidation-reduction and precipitation-dissolution reactions (Caporale and Violante, 2016). Due to the low solubility of $\mathrm{Pb}$ and its high affinity for absorption, $\mathrm{Pb}$ accumulates at the soil surface.

Unlike some heavy metals, $\mathrm{Pb}$ has no essential function in the life cycles of organisms. It only has a negative influence on living organisms. Depending on the concentration of the heavy metal, it can behave as an activator, a stimulator or a poisonous substance (Kugelman and Chin, 1971). It is well known that heavy metals such as $\mathrm{Pb}$, in higher concentrations, may cause cell-membrane disruption, the inhibition of cell division and enzyme activity as well as protein denaturation. On the other hand, the presence of heavy metals in the environment may change the properties or activate components present in the environment, which can also have an effect, negative or positive, on the activity of microorganisms and thus on the final result of the biological process (Abdu et al., 2016; Blagodatskaya et al., 2006). In addition, a reduction in soil enzyme activity (dehydrogenase, urease) has been observed in the presence of high levels of $\mathrm{Pb}$ contamination (Furtak and Gajda, 2017; Pająk et al., 2016).

Although methane may be produced in arable soil in anaerobic zones (e.g. as a result of flooding or rainy periods), the issue of the influence of $\mathrm{Pb}$ on methanogenesis in the temperate zone has been poorly investigated. We were able to find only one study in which the authors had determined the impact of $\mathrm{Pb}$ on methane production. However, this research was carried out on tropical rice soils with the addition of only one dose of lead salt (Mishra et al., 1999). Therefore, the aim of this study was to investigate methanogenesis in arable soils contaminated with $\mathrm{Pb}$ doses at the maximum permitted level and at a dose far exceeding this limit.

\section{MATERIALS AND METHODS}

Three mineral arable soils were used: Eutric Cambisol, Haplic Podzol and Mollic Gleysol. They were collected from a depth of 0-20 cm, air-dried and sieved to $<2 \mathrm{~mm}$. The soils were characterized by similar air-water conditions, as a result of their similar textures (sandy loam and loamy sand). The main difference between the soils was the $\mathrm{C}_{\text {org }}$ content (Walkiewicz et al., 2018; Wnuk et al., 2017). The basic properties of the tested soils are given in Table 1 .

The particle-size distribution (PSD) was measured for texture determination using the laser diffraction method and a Mastersizer 2000 (Malvern, UK) with a Hydro 2000G dispersion unit (Bieganowski et al., 2018). Organic and dissolved carbon contents were determined using a TOC-VCPH analyser (Shimadzu, Japan). The soil $\mathrm{pH}$ was determined potentiometrically in $1 \mathrm{~mol} \mathrm{KCl}$ and in $\mathrm{H}_{2} \mathrm{O}(1: 2.5 \mathrm{v} / \mathrm{v})$ at room temperature, after a 24 hour period of stabilization. The measurement was made using an HQ40D portable multimeter (Hach Lange). The $\mathrm{pH}$ values obtained are presented in Table 2. The $\mathrm{Pb}$ contents in the tested soils were determined by ICP-OES (inductively coupled plasma optical emission spectrometry) using an iCAP 6500 Series apparatus from Thermo Fisher Scientific, with a charge injection device (CID) detector (Kitowski et al., 2014). The phosphorus content was measured according to the PN-R-04024:1997 standard, using the colorimetric method.

Table 1. The basic properties of investigated soils

\begin{tabular}{|c|c|c|c|c|c|c|c|c|c|}
\hline \multirow{2}{*}{ Soil } & \multicolumn{3}{|c|}{$\begin{array}{l}\text { Particle-size } \\
\text { distribution }\end{array}$} & \multirow{2}{*}{$\begin{array}{c}\text { Native } \\
\mathrm{Pb} \\
\text { content } \\
\left(\mathrm{mg} \mathrm{kg}^{-1}\right)\end{array}$} & \multirow{2}{*}{$\begin{array}{l}\mathrm{C}_{\text {org }} \\
(\%)\end{array}$} & \multirow{2}{*}{$\begin{array}{c}\mathrm{DOC} \\
\left.\mathrm{mg} \mathrm{dm}^{-3}\right)\end{array}$} & \multirow{2}{*}{$\mathrm{NH}_{4}^{+}$} & \multirow{2}{*}{$\frac{+\mathrm{P}}{(\mathrm{mg} \mathrm{k}}$} & \multirow{2}{*}{$\begin{array}{l}\text { Initial } \\
\mathrm{Cl} \\
\left.\mathrm{g}^{-1}\right)\end{array}$} \\
\hline & Sand & $\begin{array}{l}\text { Clay } \\
\%)\end{array}$ & Silt & & & & & & \\
\hline $\begin{array}{l}\text { Eutric } \\
\text { Cambisol }\end{array}$ & 71.6 & 25.1 & 3.23 & 6.87 & 1.18 & 63.76 & 4.20 & 180 & 2.2 \\
\hline $\begin{array}{l}\text { Haplic } \\
\text { Podzol }\end{array}$ & 74.6 & 22.3 & 3.04 & 2.32 & 0.43 & 61.05 & 0.49 & 300 & 6.3 \\
\hline $\begin{array}{l}\text { Mollic } \\
\text { Gleysol }\end{array}$ & 74.8 & 21.7 & 3.93 & 7.49 & 3.93 & 65.7 & 2.84 & 297 & 8.6 \\
\hline
\end{tabular}

Table 2. Values of $\mathrm{pH}$ in the tested soils (Eutric Cambisol, Haplic Podzol, Mollic Gleysol) before and after incubation for methane production

\begin{tabular}{lccccccc}
\hline & \multicolumn{8}{c}{$\mathrm{pH}$} \\
\cline { 2 - 8 } Type of soil & \multicolumn{7}{c}{ After incubation } \\
\cline { 2 - 8 } & $\mathrm{H}_{2} \mathrm{O}$ & $\mathrm{KCl}$ & $\mathrm{H}_{2} \mathrm{O}$ & $\mathrm{CaCl}_{2}$ & $\mathrm{CaCl}_{2} \mathrm{x} 5$ & $\mathrm{~Pb}$ & $\mathrm{Pbx} 5$ \\
\hline E. Cambisol & 6.47 & 6.38 & 6.79 & 6.39 & 5.93 & 5.94 & 3.95 \\
H. Podzol & 6.56 & 6.5 & 6.78 & 6.41 & 6.22 & 6.12 & 4.3 \\
M. Gleysol & 6.72 & 7.71 & 7.17 & 6.99 & 6.7 & 6.71 & 5.4 \\
\hline
\end{tabular}

The $\mathrm{CH}_{4}$ concentration was measured chromatographically every week or every two weeks, for 160 days. For the measurements, a Shimadzu GC-2014 (Japan) gas chromatograph with an AOC-5000 auto injector was used, it was equipped with a flame ionization detector (FID) for $\mathrm{CH}_{4}$. Helium $(\mathrm{He})$ was used as a carrier gas at a rate of $33 \mathrm{~cm}^{3} \mathrm{~min}^{-1}$. The column temperature was 30 and $150^{\circ} \mathrm{C}$. 
The measurements were based on the $\mathrm{CH}_{4}$ production (methanogenesis) in the headspace of the soil sample contaminated with $\mathrm{Pb}$, during the allotted incubation time. $\mathrm{Pb}$ was added (in the form of $\mathrm{PbCl}_{2}$ ) in amounts determined by the limit values established by the Sewage Sludge Directive (86/278/EEC). Lead was added in two doses - the maximum $\mathrm{Pb}$ concentration permitted in arable soils (denoted $\mathrm{Pb}\left(300 \mathrm{mg} \mathrm{kg}^{-1}\right)$ ) and a five-fold higher value (denoted Pbx5 (1.500 mg kg $\left.{ }^{-1}\right)$ ). Two types of controls were used: $\mathrm{H}_{2} \mathrm{O}$ and $\mathrm{CaCl}_{2}$. $\mathrm{CaCl}_{2}$ was added in an amount providing the same concentration of chloride ions as was obtained in the tested samples (Wnuk et al., 2017). The calcium chloride control was used to observe the influence of chloride ions on the process of methane production in the soil.

For the experiments, $10 \mathrm{~g}$ of air-dried soil samples were used. Samples were flooded with $5 \mathrm{ml}$ of heavy-metal solution, or $\mathrm{H}_{2} \mathrm{O}$ or $\mathrm{CaCl}_{2}$ solution for the control samples. Then, all of the bottles were tightly closed with rubber stoppers and aluminium caps. In order to obtain the anaerobic conditions necessary for the $\mathrm{CH}_{4}$ production process, the headspace of each sample was purged with pure nitrogen. The samples were incubated in $120 \mathrm{~cm}^{3}$ glass bottles in the dark at $25^{\circ} \mathrm{C}$. Three independent replicates were used for each treatment. On the last day of incubation, the bottles were opened, and the $\mathrm{pH}$ was measured.

Based on the results obtained, the methane production rates were calculated by subtracting the final gas concentration from the initial concentration and dividing by the number of incubation days. The results were statistically analysed using a non-parametric Kruskal-Wallis test (Statistica 10 software) to determine any significant differences.

\section{RESULTS}

The increases in methane concentration in the tested samples during the incubation time are shown in Fig. 1 and the methane production rates are shown in Table 3 .

By analysing the process of methane production in the soil, three phases can be identified (Fig. 1): i) the lag phase was the same in all experiments, as there was no methane production in this time interval; ii) phase I - when a rapid increase in the concentration of the gas produced was observed, and iii) phase II - when production slowed down. The confirmation necessary to distinguish between phases I and II was the statistically significant differences in $\mathrm{CH}_{4}$ production in all of the investigated variants: both the leadcontaminated and the control cases.

The lag phase was the same in all soils and was equal to 14 days. After that time, the production of methane began. However, the efficiency of methane production was dependent on the soil and the dose of calcium chloride. While the lag phase was generally the same for all soils, the duration of the first phase of methanogenesis in Mollic Gleysol (Fig. 1c) was shorter than that in Eutric Cambisol and Haplic Podzol (Fig. 1a, b).
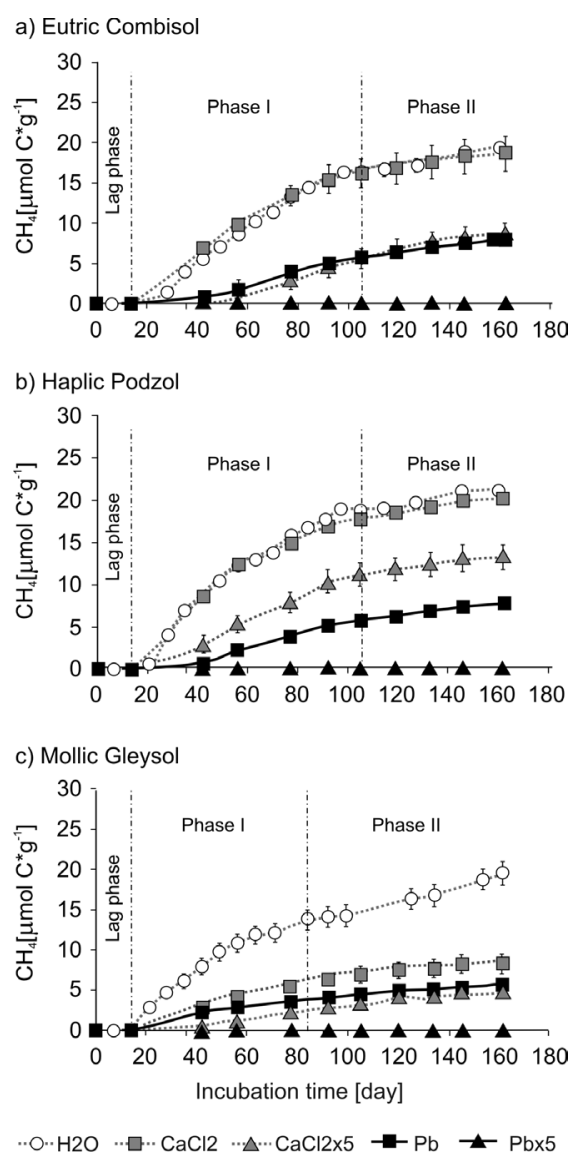

Fig. 1. Increases in the $\mathrm{CH}_{4}$ concentration with time in the headspace of the tested soils (Eutric Cambisol, Haplic Podzol, Mollic Gleysol) in the controls (soil with water and $\mathrm{CaCl}_{2}$ ) and in soils contaminated with $\mathrm{Pb}$ in two doses: the maximum $\mathrm{Pb}$ concentration in arable soils $(\mathrm{Pb})$ and a five-fold higher value $(\mathrm{Pbx} 5)$. As a second control, $\mathrm{CaCl}_{2}$ solution was used to provide the same concentration of chloride ions corresponding to the concentration obtained in the case of lead salt in particular variants of the experiment. Points are averages of triplicate samples; bars indicate standard deviations.

The $\mathrm{CH}_{4}$ production rates in Haplic Podzol and Eutric Cambisol were similar (Fig. 1a, b). In both cases, there were practically no differences between the controls with water and a lower dose of $\mathrm{CaCl}_{2}$. Furthermore, in both cases, the emission of methane was significantly lower for a higher dose of $\mathrm{CaCl}_{2}$, though for Eutric Cambisol the decrease was greater than it was for Haplic Podzol. The situation was different for Mollic Gleysol (Fig. 1c). The influence of chloride ions was much more significant in this soil, and methanogenesis was reduced even with the lower dose of $\mathrm{CaCl}_{2}$. For Mollic Gleysol, the inhibitory effect of a higher dose of $\mathrm{Cl}^{-}$on $\mathrm{CH}_{4}$ production was even greater than the effect of the lower dose of $\mathrm{PbCl}_{2}$.

The influence of chloride ions on $\mathrm{CH}_{4}$ emission is shown in Table 3. It is very clear when comparing $\mathrm{CH}_{4}$ production rates in the first phase of the process (shown in Fig. 1). In all cases, an increase in $\mathrm{Cl}^{-}$concentration produced a decrease in methanogenesis. The rate in phase II was almost independent of the concentration of chloride 
ions for Eutric Cambisol and Haplic Podzol. The situation was slightly different for Mollic Gleysol, because in this case it was difficult to identify the border between phase I and phase II. The value indicated in Fig. 1c was assumed rather arbitrarily, and this could be the reason why the value for $\mathrm{CH}_{4}$ production in this soil in the second phase without $\mathrm{CaCl}_{2}$ was higher than with the addition of $\mathrm{CaCl}_{2}$ (Table 3 ).

Table 3. Methane production rate in the investigated soils without (controls) and with two $\mathrm{Pb}$ doses

\begin{tabular}{|c|c|c|c|}
\hline \multirow[t]{2}{*}{ Variants } & \multirow{2}{*}{$\begin{array}{c}\text { Lag phase } \\
\text { duration } \\
\text { (days) }\end{array}$} & \multicolumn{2}{|c|}{$\begin{array}{c}\mathrm{CH}_{4} \text { production rate } \\
\left(\mu \mathrm{mol} \mathrm{Cg}^{-1} \mathrm{~d}^{-1}\right)\end{array}$} \\
\hline & & Phase I & Phase II \\
\hline \multicolumn{4}{|c|}{ Eutric Cambisol } \\
\hline $\mathrm{H}_{2} \mathrm{O}$ & 14 & $0.196 \pm 0.011 \mathbf{a}$ & $0.063 \pm 0.01 \mathbf{a}$ \\
\hline $\mathrm{CaCl}_{2}$ & 14 & $0.149 \pm 0.028 \mathrm{~A}^{*}$ & $0.042 \pm 0.006 \mathbf{A}^{*}$ \\
\hline $\mathrm{CaCl}_{2} \times 5$ & 14 & $0.087 \pm 0.019 \mathbf{A}^{*}$ & $0.044 \pm 0.015 \mathrm{~A}$ \\
\hline $\mathrm{Pb}$ & 14 & $0.078 \pm 0.009 \mathbf{b B}$ & $0.036 \pm 0.001 \mathbf{b A}$ \\
\hline $\mathrm{Pbx} 5$ & 0 & $0 \mathbf{b B}$ & $0 \mathbf{b B}$ \\
\hline \multicolumn{4}{|c|}{ Haplic Podzol } \\
\hline $\mathrm{H}_{2} \mathrm{O}$ & 14 & $0.196 \pm 0.011 \mathbf{a}$ & $0.047 \pm 0.004 \mathbf{a}$ \\
\hline $\mathrm{CaCl}_{2}$ & 14 & $0.145 \pm 0.013 \mathbf{A}^{*}$ & $0.037 \pm 0.005 \mathbf{A}^{*}$ \\
\hline $\mathrm{CaCl}_{2} \times 5$ & 14 & $0.135 \pm 0.005 \mathbf{A}^{*}$ & $0.033 \pm 0.002 \mathbf{A}^{*}$ \\
\hline $\mathrm{Pb}$ & 14 & $0.079 \pm 0.004 \mathbf{b B}$ & $0.034 \pm 0.007 \mathbf{b A}$ \\
\hline $\mathrm{Pbx} 5$ & 0 & $0 \mathbf{b B}$ & $0 \mathbf{b B}$ \\
\hline \multicolumn{4}{|c|}{ Mollic Gleysol } \\
\hline $\mathrm{H}_{2} \mathrm{O}$ & 14 & $0.172 \pm 0.014 \mathbf{a}$ & $0.077 \pm 0.004 \mathbf{a}$ \\
\hline $\mathrm{CaCl}_{2}$ & 14 & $0.068 \pm 0.013 \mathbf{A}^{*}$ & $0.029 \pm 0.005 \mathbf{A}^{*}$ \\
\hline $\mathrm{CaCl}_{2} \times 5$ & 14 & $0.044 \pm 0.003 \mathbf{A}^{*}$ & $0.026 \pm 0.005 \mathbf{A}^{*}$ \\
\hline $\mathrm{Pb}$ & 14 & $0.037 \pm 0.006 \mathbf{b B}$ & $0.022 \pm 0.005 \mathbf{b A}$ \\
\hline $\mathrm{Pbx} 5$ & 0 & $0 \mathbf{b B}$ & $0 \mathbf{b B}$ \\
\hline
\end{tabular}

The same letter means no statistically significant differences among the rates; an asterisk indicates statistical differences between the control sample with $\mathrm{H}_{2} \mathrm{O}$ and $\mathrm{CaCl}_{2}$; small letters indicate statistical differences between the control with water and the contaminated sample; capital letters mean statistical differences between the control with $\mathrm{CaCl}_{2}$ and the test sample (non-parametric Kruskal-Wallis test, $\mathrm{p}<0.05$, separate for each tested soil)

The addition of chloride ions also had an influence on changes in $\mathrm{pH}$ in the investigated soils (Table 2). In all cases, a higher $\mathrm{Cl}^{-}$concentration caused a lower $\mathrm{pH}$ value. The changes varied from 0.86 units (for Eutric Cambisol) to 0.41 units (for Mollic Gleysol).

After the enrichment of the tested soils with $\mathrm{Pb}^{2+}$, the lag phase preceding $\mathrm{CH}_{4}$ emission lasted for the same time as in samples without these ions (Fig. 1 and Table 3).

The addition of $\mathrm{Pb}$ significantly changed the methanogenesis rate in all tested soils (Fig. 1). The single $\mathrm{Pb}$ dose caused a significant slowing of the process in all cases. The higher dose of $\mathrm{Pb}$ (by five times) caused a total inhibition of $\mathrm{CH}_{4}$ production in all soils used in the experiments.

As in the case of the control with chloride ions, the differences in methanogenesis described above found confirmation in the analysis of the methane production rate, as shown in Table 3. Considering the changes in rates in the first phase (shown in Fig. 1), it may be seen that for all soils, the decrease in $\mathrm{CH}_{4}$ production for the control with $\mathrm{CaCl}_{2}$ and for the sample with $\mathrm{PbCl}_{2}$ was practically the same, at $\sim 1.85$. With a higher $\mathrm{Pb}^{2+}$ concentration, methane production was stopped in all soils, and therefore in these cases the methane production rate was zero.

The $\mathrm{pH}$ values of samples contaminated with $\mathrm{Pb}$ were lower in all cases than those of the corresponding controls, including the controls with $\mathrm{CaCl}_{2}$ (Table 2). A greater $\mathrm{pH}$ decrease was observed after the application of the higher $\mathrm{Pb}$ dose. For instance, in Eutric Cambisol and Haplic Podzol, there was a change of almost two $\mathrm{pH}$ units.

\section{DISCUSSION}

The ability of soil to produce and emit methane to the atmosphere is regulated by many factors connected mainly with soil properties, such as the particle-size distribution, fertilization, the $\mathrm{pH}$ or the $\mathrm{C}_{\text {org }}$ content, which simultaneously affect the behaviour of heavy metals in the soil. All of the tested soils showed the biphasic production of $\mathrm{CH}_{4}$ (Fig. 1), but some differences in the process rate were detected (Table 3). Cambisol and Podzol showed a similar rate of $\mathrm{CH}_{4}$ emission in both phases of the process. Mollic Gleysol showed a lower methanogenic potential. The rate in phase II was always much lower than that in phase I.

Angel et al. (2012) tested the methanogenic potential of soils collected from all over the world by flooding their soil samples. The results showed that in almost all samples, methane production started within seven to 14 days of incubation. What is more, the methane production rate was not connected with parameters such as organic matter content or atmospheric precipitation. A similar tendency may be observed in our results. In almost all of the tested soil samples, the time required for methane production to begin was around 14 days. Additionally, no connection between higher $\mathrm{C}_{\text {org }}$ content and methanogenic activity was detected. The highest methane production rates were observed for Haplic Podzol where the $\mathrm{C}_{\text {org }}$ content was $0.43 \%$ and the lowest methane production rate was found in Mollic Gleysol, which is distinguished by the highest $\mathrm{C}_{\text {org }}$ concentration at $3.93 \%$. A possible reason for this may be the poor quality of the available $\mathrm{C}_{\text {org }}$ (Guérin et al., 2008).

The initial soil $\mathrm{pH}$ is another factor which may affect methanogenesis. Two out of the three soils tested had similar $\mathrm{pH}$ values - Eutric Cambisol at 6.38 and Haplic Podzol at 6.5. The highest $\mathrm{pH}$ values were detected in Mollic Gleysol, at 7.71. Despite this, the observed methane production rates were similar. One reason for this was given by Yang and Chang (1998) who tested the effects of a few factors, such as water content, organic substances, oxygen and initial $\mathrm{pH}$, on methane production in paddy soil. The measurements were taken at $\mathrm{pH}$ values in the range of 3.2 to 9.3. The results showed no differences in the process 
at $\mathrm{pH}$ values between 6.5 and 7.7 , which is similar to the range of $\mathrm{pH}$ values observed in our research. Higher and lower $\mathrm{pH}$ values outside the given range caused a slowing or (at extreme values) a complete inhibition of the process.

It has been shown that $\mathrm{NH}_{4}{ }^{+}$in the soil may also affect the process of methane production (Fotidis et al., 2013; Hao et al., 2017; Lv et al., 2014). Experimental results have shown that a lower $\mathrm{NH}_{4}{ }^{+}$content led to higher methane production rates in the tested soils. In our measurements, differences in the methane production rate in the tested soils may be observed compared to the controls with water. The highest values were obtained with Haplic Podzol, followed by Mollic Gleysol. The lowest values were found in Eutric Cambisol. These differences may be related to the different ammonium ion content in the different soils. The highest concentration of $\mathrm{NH}_{4}^{+}$ions in our study was observed in Eutric Cambisol $\left(4.20 \mathrm{mg} \mathrm{kg}^{-1}\right)$ and the lowest value was observed in Haplic Podzol $\left(0.49 \mathrm{mg} \mathrm{kg}^{-1}\right)$, which is consistent with the statement above. However, it should be pointed out that the initial $\mathrm{NH}_{4}^{+}$content in the tested soil was quite low, and therefore this parameter was not treated as a key variable in our experiment.

Another possible reason for differences in the course of the methane production process might be connected with the presence of salt ions. In the research, two types of controls were used: samples mixed with water or with $\mathrm{CaCl}_{2}$ solution. Calcium has a positive effect on the growth of methanogens to a limited extent (Kumar et al., 2016; Murray and Zinder, 1985). Chloride $\left(\mathrm{Cl}^{-}\right)$is usually supposed to be unreactive in soil, but some authors have reported its participation in biogeochemical cycles (Bastviken et al., 2007; Gustavsson et al., 2012; Öberg and Sandén, 2005). Analysis of the course of methane production in all tested soils showed differences between the results of the two controls. A possible reason for this is the effect of chloride ions on methanogenesis, because the influence of calcium ions, in light of the available literature, seems to be negligible. Ahn et al. (2006) examined the effect of calcium ions on the anaerobic digestion of wastewater. The results showed that despite the changes in calcium concentration in the reactors, the methane yield did not change. Van Langerak et al. (1998) came to a similar conclusion while testing the effect of calcium on methanogenic sludge.

Although the use of chloride salts as a control is common in methane production research (Altaş, 2009; Basiliko and Yavitt, 2001; Muñoz et al., 1996), there are only a few reports available concerning the possible effect of these ions on the process. It has been stated that $\mathrm{Cl}^{-}$may cause a reduction in $\mathrm{CH}_{4}$ production (Jagadeesh Babu et al., 2006; Koyama and Kimura, 1998). A possible reason for this is osmotic imbalance, which affects the cation-anion equilibrium. The disturbance of the existing balance leads to a reduction in the activity of methanogens or microorganisms which provide substrates for reactions (Mishra et al., 2003). In our study, the negative influence of $\mathrm{CaCl}_{2}$ on $\mathrm{CH}_{4}$ emission was measured in all soils enriched with a higher $\mathrm{Cl}^{-}$dose (Fig. 1, Table 3), while in Mollic Gleysol, even the lower $\mathrm{Cl}^{-}$concentration led to a reduced ability to produce $\mathrm{CH}_{4}$.

As in the controls, after the addition of the lower concentration of $\mathrm{Pb}$, a lag phase followed by a biphasic pattern of $\mathrm{CH}_{4}$ emission was observed. The methane production curves showed the strong negative effect of $\mathrm{Pb}$ at a concentration of $300 \mathrm{mg} \mathrm{kg}^{-1}$, compared to the corresponding controls. The higher heavy-metal dose (1500 mg kg-1) caused a total inhibition of the process.

The analysis of the effect of $\mathrm{Pb}$ on the process of methane production may be considered in several ways. However, we should take into consideration the fact that the influence of $\mathrm{Pb}$ on methanogenesis may be concurrent with the impact of $\mathrm{CaCl}_{2}$. One important aspect to consider is the direct impact of the metal ion on soil microorganisms.

The effect of $\mathrm{Pb}$ contamination on soil microorganisms is regulated by the soil's physicochemical properties, since these affect the heavy metal's mobility and, as a consequence, its bioavailability. It was proven that a higher organic matter and clay content leads to lower $\mathrm{Pb}$ availability, and hence the reduced negative effect on the microbial community (Alvim Ferraz and Lourenco, 2000; Zeng et al., 2006). Mollic Gleysol, had the highest organic matter content of the samples tested, and was less sensitive to $\mathrm{Pb}$ contamination than the other soils investigated (Table 3 ). This may be the result of the creation of complexes with organic acids, thereby decreasing the solubility and mobility of heavy metals, especially $\mathrm{Pb}$ (Antić-Mladenović et al., 2017; Laing et al., 2009).

The impact of phosphate on the behaviour of $\mathrm{Pb}$ has also been noted. Phosphate in soil causes the immobilization of $\mathrm{Pb}$ by reducing its mobility and bioavailability. The main reason is the formation of insoluble pyromorphite complexes (Kelebemang et al., 2017; Sanderson et al., 2016). The soils used in our experiments were characterized by a very high phosphorus content (Table 1), which may also partially protect methanogens against the harmful effects of $\mathrm{Pb}$ at lower doses, leading to a reduction in (but not a total inhibition of) $\mathrm{CH}_{4}$ production.

A study of the microbial community in the presence of $\mathrm{Pb}$ ions allowed the concentration limit for causing a decrease in microbial activity to be determined (above $300 \mathrm{~m} \mathrm{~kg}^{-1}$ ). Lower concentrations caused the stimulation of microbial activity. In our research, a concentration of $300 \mathrm{mg} \mathrm{kg}^{-1}$ caused a reduction in microbiological activity (observed as a slowdown in the production of methane). These differences probably resulted from the use of $\mathrm{Pb}$ in the form of lead acetate, since acetate is an organic carbon compound and hence may stimulate the activity of soil microbes (Loka Bharathi et al., 1990).

There are few reports on the direct effect of $\mathrm{Pb}$ on the process of methane production in soil. Mishra et al. (1999) tested the effect of a few heavy metals (including $\mathrm{Pb}$ ) on the process of methane production in three types of Indian soils: 
alluvial soil, laterite soil and acid sulphate soil. The metal was added to obtain a final concentration of $20 \mu \mathrm{g} \mathrm{g}^{-1}$ in the soil. The results showed that the methanogenesis process was inhibited in the soil samples after 20 days of incubation. According to our research results, $\mathrm{CH}_{4}$ production did not even begin at the higher $\mathrm{Pb}$ concentration. At the lower concentration, $\mathrm{CH}_{4}$ production was inhibited after 40 days of incubation in Haplic Podzol and Eutric Cambisol, and after 60 days of incubation in Mollic Gleysol. This showed that Mollic Gleysol was the least sensitive to $\mathrm{Pb}$ addition. The process of methane production can also be observed in other ecosystems where anoxic conditions occur. Muñoz et al. (1996) investigated methane production in sludge enriched by nickel, lead and a combination of these two heavy metals. $\mathrm{Pb}$ was added at three levels, one of which was close to our tested value $\left(500 \mathrm{mg} \mathrm{kg}^{-1}\right)$. In contrast to our results, the authors stated that $\mathrm{Pb}$ did not show any long-term inhibitory effect.

When considering the influence of $\mathrm{Pb}$ on methanogenesis, it is necessary to pay attention to the conditions prevailing during the process. Anaerobic conditions are necessary, in order to initiate $\mathrm{CH}_{4}$ production. These conditions were obtained by flooding the samples and removing atmospheric air from the headspace. In this environment, the properties of the heavy metal may change, as they are connected with a decrease in soil redox potential (Eh) (Penning and Conrad, 2007; Sun et al., 2007). It has been shown that Eh has an effect on the solubility and availability of heavy metals: a low Eh value (together with an increase in $\mathrm{pH}$ caused by flooding) causes a decrease in $\mathrm{Pb}$ solubility and mobility, connected mainly with complexation with soil organic matter but also with clay minerals or Fe and Mn hydroxides (Antić-Mladenović et al., 2017; Laing et al., 2009; Rinklebe et al., 2016; Sun et al., 2007). In our research, $\mathrm{Pb}$ caused a slowdown in or a total inhibition of the methanogenesis process, depending on the $\mathrm{Pb}$ level (Fig. 1). The behaviour of $\mathrm{Pb}$ after flooding may depend on the duration of this condition. At very low Eh values (below -150 mV (Gambrell et al., 1991; Mansfeldt, 2004) or $-220 \mathrm{mV}$ (Ross, 1989)) sulphide formation is also possible (Rinklebe et al., 2016), and these ions may bond with $\mathrm{Pb}$. The appropriate redox potential for methanogenesis is also in this range (Chowdhury and Dick, 2013; Joulian et al., 1997). After a longer period (more than two months), the immobilization of trace metals by precipitation or readsorption may occur (Charlatchka and Cambier, 2000), and this may be the mechanism regulating $\mathrm{CH}_{4}$ emission in phase II in our study.

As mentioned previously, $\mathrm{pH}$ is also an important factor affecting the process of methane production in contaminated samples. The optimal $\mathrm{pH}$ value for methanogenesis is in the range of 6-8, depending on the source (Yang and Chang, 1998). For each sample, the addition of $\mathrm{Pb}$ caused a decrease in $\mathrm{pH}$, compared with the corresponding con- trol sample. In samples with the lower $\mathrm{Pb}$ dose, the highest decrease was observed in Eutric Cambisol, with similar decreases being observed in Haplic Podzol and Mollic Gleysol. However, the $\mathrm{pH}$ values were still in the optimal range for methanogens, where it is possible for them to produce methane. In samples contaminated with $\mathrm{Pb}$ in the five-fold dose, the $\mathrm{pH}$ decrease was much higher (Table 2). In both cases, it may be stated that the changes in $\mathrm{pH}$ were connected with a decrease in the methane production rate. In the five-fold dose, the process was completely inhibited. The same effect has been observed by other authors. The addition of $\mathrm{Pb}^{2+}$ caused changes in the $\mathrm{pH}$ values, which in turn led to differences in methane production, mainly to inhibition (Gogo and Pearce, 2009; Keller and Wade, 2018). A possible reason for this may be the release of $\mathrm{H}^{+}$ ions via cation exchange in the presence of trace metals. However, this is a subject that requires further research.

Our short-term experiment showed the importance of observing the permissible doses of heavy metals in arable soils where $\mathrm{Pb}$-induced $\mathrm{CH}_{4}$ imbalance may occur. On the one hand, exceeding the permitted $\mathrm{Pb}$ doses may reduce $\mathrm{CH}_{4}$ emissions, but it also has a negative effect on its oxidation in these soils (Wnuk et al., 2017). In such cases, the accumulation of heavy metals may result in $\mathrm{CH}_{4}$ emissions from cultivated soils. The real environmental effect may be demonstrated by long-term field studies in this area, and precise mechanisms may be found using microbiological studies.

\section{CONCLUSIONS}

1. The lowest methane production rate was measured in Mollic Gleysol. The results obtained for Eutric Cambisol and Haplic Podzol were similar to each other.

2. The addition of $\mathrm{Pb}$ caused a lower production of methane (for the single dose) or the total inhibition of production (for the five-fold dose).

3. An analysis of the results for the control samples showed that the effect of changes in salt ion concentration may be observed. It is supposed that chloride ions were responsible for the slightly lower methane concentration in the sample corresponding to the control with water.

Conflict of interest: The authors declare that they have no conflict of interest.

\section{REFERENCES}

Abdu N., Abdullahi A.A., and Abdulkadir A., 2016. Heavy metals and soil microbes. Environ. Chem. Lett., 15, 1-20, https://doi.org/10. 1007/s10311-016-0587-x

Ahn J.H., Do T.H., Kim S.D., and Hwang S., 2006. The effect of calcium on the anaerobic digestion treating swine wastewater. Biochem. Eng. J., 30, 33-38, https://doi.org/10.1016/j. bej.2006.01.014

Altaş L., 2009. Inhibitory effect of heavy metals on methane-producing anaerobic granular sludge. J. Hazard. Mater., 162, 1551-1556, https://doi.org/10.1016/j.jhazmat.2008.06. 048. 
Alvim Ferraz M.C.M., and Lourenco J.C.N., 2000. The Influence of Organic Matter Content of Contaminated Soils on the Leaching Rate of Heavy Metals. Environ. Prog., 19, 53-58.

Angel R., Claus P., and Conrad R., 2012. Methanogenic archaea are globally ubiquitous in aerated soils and become active under wet anoxic conditions. ISME J., 6, 847-862, https:// doi.org/10. 1038/ismej.2011.141

Antić-Mladenović S., Frohne T., Kresović M., Stark H.-J., Tomić Z., Licina V., and Rinklebe J., 2017. Biogeochemistry of $\mathrm{Ni}$ and $\mathrm{Pb}$ in a periodically flooded arable soil: Fractionation and redox-induced (im)mobilization. J. Environ. Manage., 186, 141-150, https://doi.org/10.1016/j. jenvman.2016.06.005

Basiliko N. and Yavitt J.B., 2001. Influence of $\mathrm{Ni}, \mathrm{Co}, \mathrm{Fe}$, and $\mathrm{Na}$ additions on methane production in Sphagnumdominated Northern American peatlands. Biogeochemistry, 52, 133-153, https://doi.org/10.1023/A:1006461803585

Bastviken D., Thomsen F., Svensson T., Karlsson S., Sanden P., Shaw G., Matucha M., and Oberg G., 2007. Chloride retention in forest soil by microbial uptake and by natural chlorination of organic matter. Geochemica Cosmochim. Acta, 71, 3182-3192, https://doi.org/10.1016/j.gca.2007.04.028

Bieganowski A., Ryżak M., Sochan A., Barna G., Hernadi H., Beczek M., Polakowski C., and Mako A., 2018. Laser diffractometry in the measurements of soil and sediment particle size distribution. Adv. Agron., 151, 215-279, https://doi.org/ 10.1016/bs.agron.2018.04.003

Blagodatskaya E. V, Pampura T. V, Dem'yanova E.G., and Myakshina T.N., 2006. Effect of lead on growth characteristics of microorganisms in soil and rhizosphere of Dactylis glomerata. Eurasian Soil Sci., 39, 653-660, https://doi. org/10.1134/S106422930606010X

Bodelier P.L. and Steenbergh A.K., 2014. Interactions between methane and the nitrogen cycle in light of climate change. Curr. Opin. Environ. Sustain., 9-10, 26-36, https://doi. org/10.1016/j.cosust.2014.07.004.

Brzezińska M., Nosalewicz M., Pasztelan M., and Włodarczyk T., 2012. Methane production and consumption in loess soil at different slope position. Sci. World J., 2012, 1-8, https:// doi.org/10.1100/2012/620270

Caporale A.G. and Violante A., 2016. Chemical processes affecting the mobility of heavy metals and metalloids in soil environments. L. Pollut., 2, 15-27, https://doi.org/ 10.1007/ s40726 -015-0024-y

Charlatchka R. and Cambier P., 2000. Influence of reducing conditions on solubility of trace metals in contaminated soils. Water. Air. Soil Pollut., 118, 143-167.

Chowdhury T.R. and Dick R.P., 2013. Ecology of aerobic methanotrophs in controlling methane fluxes from wetlands. Appl. Soil Ecol., 65, 8-22, https://doi.org/10.1016/j.apsoil. 2012.12.014.

Contin M., Goi D., De Nobili M., 2012. Land application of aerobic sewage sludge does not impair methane oxidation rates of soils. Sci. Total Environ., 441, 10-18, https://doi. org/10.1016/j.scitotenv.2012.09.052

Einola J.K.M., Kettunen R.H., and Rintala J.A., 2007. Responses of methane oxidation to temperature and water content in cover soil of a boreal landfill. Soil Biol. Biochem., 39, 11561164, https://doi.org/10.1016/j.soilbio.2006.12.022
Fotidis I.A., Karakashev D., Kotsopoulos T.A., Martzopoulos G.G., and Angelidaki I., 2013. Effect of ammonium and acetate on methanogenic pathway and methanogenic community composition. FEMS Microbiol. Ecol., 83, 38-48, https://doi.org/10.1111/j.1574-6941.2012.01456.x

Fronzek S., Pirttioja N., Carter T.R., Bindi M., Ho H., Palosuo T., Ruiz-ramos M., Tao F., Trnka M., Acutis M., Asseng S., Baranowski P., Basso B., Bodin P., Buis S., Cammarano D., Deligios P., Destain M., Dumont B., Ewert F., Ferrise R., François L., Gaiser T., Hlavinka P., Jacquemin I., Christian K., Kollas C., Krzyszczak J., Lorite I.J., Minet J., Minguez M.I., Montesino M., Moriondo M., Müller C., Nendel C., Öztürk I., Perego A., Rodríguez A., Ruane A.C., Ruget F., Sanna M., Semenov M.A., Slawinski C., Stratonovitch P., Supit I., Waha K., Wang E., Wu L., Zhao Z., and Rötter R.P., 2018. Classifying multi-model wheat yield impact response surfaces showing sensitivity to temperature and precipitation change. Agric. Syst., 159, 209224, https://doi.org/10.1016/j.agsy.2017.08.004

Furtak K. and Gajda A.M., 2017. Activity of dehydrogenases as an indicator of soil environment quality. Polish J. Soil, 50, 33-40, https://doi.org/10.17951/pjss/2017.50.1.33

Gambrell R.P., Wiesepape J.B., Patrick W.H., and Duff M.C., 1991. The effects of $\mathrm{pH}$, redox, and salinity on metal release from a contaminated sediment. Water. Air. Soil Pollut., 57-58, 359-367, https://doi.org/10.1007/BF00282899

Gogo S. and Pearce D.M.E., 2009. Saturation of raised bog peat exchange sites by $\mathrm{Pb}^{2+}$ and $\mathrm{Al}^{3+}$ stimulates $\mathrm{CH}_{4}$ production. Soil Biol. Biochem., 41, 2025-2028, https://doi.org/10.1016/ j.soilbio. 2009.07.015

Guérin F., Abril G., de Junet A., and Bonnet M.P., 2008. Anaerobic decomposition of tropical soils and plant material: Implication for the $\mathrm{CO}_{2}$ and $\mathrm{CH}_{4}$ budget of the Petit Saut Reservoir. Appl. Geochemistry, 23, 2272-2283, https:// doi.org/10.1016/j.apgeochem.2008.04.001

Gustavsson M., Karlsson S., Oberg G., Sanden P., Svensson T., Valinia S., Thiry Y., and Bastviken D., 2012. Organic matter chlorination rates in different boreal soils: The role of soil organic matter content. Environ. Sci. Technol. 46, 1504-1510.

Hao L.P., Mazéas L., Lü F., Grossin-Debattista J., He P.J., and Bouchez T., 2017. Effect of ammonia on methane production pathways and reaction rates in acetate-fed biogas processes. Water Sci. Technol., 75, 1839-1848, https://doi. org/10.2166/wst.2017.032

IPCC, 2014. Climate Change 2014: Synthesis Report. Contribution of Working Groups I, II and III to the Fifth Assessment Report of the Intergovernmental Panel on Climate Change.

Jagadeesh Babu Y., Nayak D.R., and Adhya T.K., 2006. Potassium application reduces methane emission from a flooded field planted to rice. Biol. Fertil. Soils, 42, 532541, https://doi.org/10.1007/s00374-005-0048-3

Joulian C., Escoffier S., Le Mer J., Neue H.U., and Roger P.A., 1997. Populations and potential activities of methanogens and methanotrophs in rice fields: relations with soil properties. Eur. J. Soil Biol., 33, 105-116.

Kabata-Pendias A., 2010. Trace Elements in Soils and Plants, Fourth Edition. CRC Press, London, https://doi.org/10.1201/ b10158-25. 
Kelebemang R., Dinake P., Sehube N., Daniel B., Totolo O., and Laetsang M., 2017. Speciation and mobility of lead in shooting range soils. Chem. Speciat. Bioavailab., 29, 143152, https://doi.org/10.1080/09542299.2017.1349552

Keller J.K. and Wade J., 2018. No evidence for trace metal limitation on anaerobic carbon mineralization in three peatland soils. Geoderma, 314, 95-101, https://doi.org/10.1016/j.geoderma. 2017.11.001

Kirschke S., Bousquet P., Ciais P., Saunois M., Canadell J.G., Dlugokencky E.J., Bergamaschi P., Bergmann D., Blake D.R., Bruhwiler L., Cameron-Smith P., Castaldi S., Chevallier F., Feng L., Fraser A., Heimann M., Hodson E.L., Houweling S., Josse B., Fraser P.J., Krummel P.B., Lamarque J.-F., Langenfelds R.L., Le Quéré C., Naik V., O'Doherty S., Palmer P.I., Pison I., Plummer D., Poulter B., Prinn R.G., Rigby M., Ringeval B., Santini M., Schmidt M., Shindell D.T., Simpson I.J., Spahni R., Steele L.P., Strode S. a., Sudo K., Szopa S., van der Werf G.R., Voulgarakis A., van Weele M., Weiss R.F., Williams J.E., and Zeng G., 2013. Three decades of global methane sources and sinks. Nat. Geosci., 6, 813-823, https://doi.org/10. 1038/ngeo 1955

Kitowski I., Sujak A., Wiącek D., Strobel W., and Rymarz M., 2014. Trace element residues in eggshells of Grey Heron (Ardea cinerea) from colonies of East Poland. North. West. J. Zool., 10, 346-354, https://doi.org/10.1080/21658005.20 13.817518 .

Koyama T. and Kimura M., 1998. Inhibitors of methane production in paddy soils. Soil Sci. Plant Nutr., 44, 667-674, https:// doi.org/10.1080/00380768.1998.10414490

Kugelman I.J. and Chin K.K., 1971. Toxicity, Synergism, and Antagonism in Anaerobic Waste Treatment Processes, 55-90, https://doi.org/10.1021/ba-1971-0105.ch005

Kumar S., Das A., Srinivas G.L.K., Dhar H., Kumar V., and Wong J., 2016. Effect of calcium chloride on abating inhibition due to volatile fatty acids during the start-up period in anaerobic digestion of municipal solid waste. Environ. Technol., 37, 1501-1509, https://doi.org/10.1080/09593330 .2015.1119204

Kuźniar A., Banach A., Stępniewska Z., Frąc M., Oszust K., Gryta A., Kłos M., and Wolińska A., 2018. Communitylevel physiological profiles of microorganisms inhabiting soil contaminated with heavy metals. Int. Agrophys., 32, 101-109, https://doi.org/10.1515/intag-2016-0096

Laing G. Du, Rinklebe J., Vandecasteele B., Meers E., and Tack F.M.G., 2009. Trace metal behaviour in estuarine and riverine floodplain soils and sediments: A review. Sci. Total Environ., 407, 3972-3985, https://doi.org/10.1016/j.scitotenv.2008. 07.025

Loka Bharathi P.A., Sathe V., and Chandramohan D., 1990. Effect of lead, mercury and cadmium on a sulphate-reducing bacterium. Environ. Pollut., 67, 361-374, https://doi. org/10. 1016/0269-7491(90)90072-K

Lukowski A. and Wiater J., 2016. The content and solubility of lead in arable soils of the Podlasie Province (eastern Poland). Soil Sci. Annu., 67, 190-196, https://doi.org/10.1515/ ssa-2016-0024
Lv Z., Hu M., Harms H., Richnow H.H., Liebetrau J., and Nikolausz M., 2014. Stable isotope composition of biogas allows early warning of complete process failure as a result of ammonia inhibition in anaerobic digesters. Bioresour. Technol., 167, 251-259, https://doi.org/10.1016/j. biortech.2014.06.029

Majdinasab A. and Yuan Q., 2017. Performance of the biotic systems for reducing methane emissions from landfill sites: A review. Ecol. Eng., 104, 116-130, https://doi.org/10.1016/j. ecoleng. 2017.04.015

Malyan S.K., Bhatia A., Kumar A., Gupta D.K., Singh R., Kumar S.S., Tomer R., Kumar O., and Jain N., 2016. Methane production, oxidation and mitigation: A mechanistic understanding and comprehensive evaluation of influencing factors. Sci. Total Environ., 572, 874-896, https://doi. org/10.1016/j.scitotenv.2016.07.182.

Mansfeldt T., 2004. Redox potential of bulk soil and soil solution concentration of nitrate, manganese, iron, and sulfate in two Gleysols. J. Plant Nutr. Soil Sci., 167, 7-16, https://doi. org/10.1002/jpln.200321204

Mishra S.R., Bharati K., Sethunathan N., and Adhya T.K., 1999. Effects of heavy metals on methane production in tropical rice soils. Ecotoxicology and Environmental Safety, 44(1), 129-136, https://doi.org/10.1006/eesa.1999. 1809

Mishra S.R., Pattnaik P., Sethunathan N., and Adhya T.K., 2003. Anion-mediated salinity affecting methane production in a flooded alluvial soil. Geomicrobiol. J., 20, 579-586, https://doi.org/10.1080/713851167

Muñoz M.A., Codina J.C., De Vicente A., Sanchez J.M., Borrego J.J., and Moriñigo M.A., 1996. Effects of nickel and lead and a support material on the methanogenesis from sewage sludge. Lett. Appl. Microbiol., 23, 339-342, https:// doi.org/10. 1111/j.1472-765X.1996.tb00203.x

Murray P.A. and Zinder S.H., 1985. Nutritional Requirements of Methanosarcina Strain TM-1. Appl. Environ. Microbiol., 50, 49-55.

Nosalewicz M., Brzezińska M., Pasztelan M., and Supryn G., 2011. Methane in the environment(a review). Acta Agroph., 18, 355-373.

Öberg G. and Sandén P., 2005. Retention of chloride in soil and cycling of organic matter-bound chlorine. Hydrol. Process., 19, 2123-2136, https://doi.org/10.1002/hyp.5680

Pająk M., Błońska E., Frąc M., and Oszust K., 2016. Functional diversity and microbial activity of forest soils that are heavily contaminated by lead and zinc. Water. Air. Soil Pollut., 227, https://doi.org/10.1007/s11270-016-3051-4

Pawłowska M., Rozej A., and Stepniewski W., 2011. The effect of bed properties on methane removal in an aerated biofilter - Model studies. Waste Manag., 31, 903-913, https://doi. org/10.1016/j.wasman.2010.10.005

Penning H. and Conrad R., 2007. Quantification of carbon flow from stable isotope fractionation in rice field soils with different organic matter content. Org. Geochem., 38, 2058-2069, https://doi.org/10.1016/j.orggeochem.2007.08.004

Rinklebe J., Shaheen S.M., and Yu K., 2016. Release of As , Ba, $\mathrm{Cd}, \mathrm{Cu}, \mathrm{Pb}$, and $\mathrm{Sr}$ under pre-de fi nite redox conditions in different rice paddy soils originating from the USA and Asia. Geoderma, 270, 21-32, https://doi.org/10.1016/j.geoderma. 2015.10.011 
Sanderson P., Naidu R., and Bolan N., 2016. The effect of environmental conditions and soil physicochemistry on phosphate stabilisation of $\mathrm{Pb}$ in shooting range soils. J. Environ. Manage., 170, 123-130, https://doi.org/10.1016/j.jenvman. 2016.01.017

Sankhla M.S., Kumari M., Nandan M., Kumar R., and Agrawal P., 2016. Heavy metal contamination in soil and their toxic effect on human health : a review study. Int. J. All Res. Educ. Sci. Methods, 4, 13-19.

Saunois M., Bousquet P., Poulter B., Peregon A., Ciais P., Canadell J.G., Dlugokencky E.J., Etiope G., Bastviken D., Houweling S., Janssens-Maenhout G., Tubiello F.N., Castaldi S., Jackson R.B., Alexe M., Arora V.K., Beerling D.J., Bergamaschi P., Blake D.R., Brailsford G., Brovkin V., Bruhwiler L., Crevoisier C., Crill P., Covey K., Curry C., Frankenberg C., Gedney N., Höglund-Isaksson L., Ishizawa M., Ito A., Joos F., Kim H.S., Kleinen T., Krummel P., Lamarque J.F., Langenfelds R., Locatelli R., Machida T., Maksyutov S., McDonald K.C., Marshall J., Melton J.R., Morino I., Naik V., O'Doherty S., Parmentier F.J.W., Patra P.K., Peng C., Peng S., Peters G.P., Pison I., Prigent C., Prinn R., Ramonet M., Riley W.J., Saito M., Santini M., Schroeder R., Simpson I.J., Spahni R., Steele P., Takizawa A., Thornton B.F., Tian H., Tohjima Y., Viovy N., Voulgarakis A., Van Weele M., Van Der Werf G.R., Weiss R., Wiedinmyer C., Wilton D.J., Wiltshire A., Worthy D., Wunch D., Xu X., Yoshida Y., Zhang B., Zhang Z., and Zhu Q., 2016. The global methane budget 2000-2012. Earth Syst. Sci. Data, 8, 697-751, https://doi.org/10.5194/essd-8-697-2016

Serrano-Silva N., Sarria-Guzmán Y., Dendooven L., and Luna-Guido M., 2014. Methanogenesis and methanotrophy in soil: a review. Pedosphere, 24, 291-307, https://doi. org/10.1016/S1002-0160(14)60016-3.

Sherene T., 2010. Mobility and transport of heavy metals in polluted soil environment. Biol. Forum - An Int. J., 2, 112-121.

Stępniewska Z., Goraj W., Kuźniar A., Banach A., Górski A., Pytlak A., and Urban D., 2018. Methane oxidation by endophytic bacteria inhabiting Sphagnum sp. and some vascular plants. Wetlands, 38, 411-422, https://doi.org/10.1007/ s13157-017-0984-3
Sun L., Chen S., Chao L., and Sun T., 2007. Effects of flooding on changes in Eh, $\mathrm{pH}$ and speciation of cadmium and lead in contaminated soil. Bull. Environ. Cintamination Toxicol., 79, 514-518, https://doi.org/10.1007/s00128-007 -9274-8

Szafranek-Nakonieczna A. and Stępniewska Z., 2015. The influence of the aeration status (ODR, Eh) of peat soils on their ability to produce methane. Wetl. Ecol. Manag., 23, 665-676, https://doi.org/10.1007/s11273-015-9410-x.

Szafranek-Nakonieczna A., Wolińska A., Zielenkiewicz U., Kowalczyk A., Stępniewska Z., and Błaszczyk M., 2018. Activity and identification of methanotrophic bacteria in arable and no-tillage soils from Lublin Region (Poland). Microb. Ecol., doi:10.1007/s00248-018-1248-3

Tate K.R., 2015. Soil methane oxidation and land-use change from process to mitigation. Soil Biol. Biochem., 80, 260-272, https://doi.org/10.1016/j.soilbio.2014.10.010

van Langerak E.P.A., Gonzalez-Gil G., van Aelst A., van Lier J.B., Hamelers H.V.M., and Lettinga G., 1998. Effects of high calcium concentrations on the development of methanogenic sludge in upflow anaerobic sludge bed (UASB) reactors. Water Res., 32, 1255-1263, https://doi.org/10.1016 /S0043 -1354(97)00335-7

VijayaVenkataRaman S., Iniyan S., and Goic R., 2012. A review of climate change, mitigation and adaptation. Renew. Sustain. Energy Rev., 16, 878-897, https://doi.org/ 10.1016/j.rser.2011.09.009

Walkiewicz A., Brzezińska M., and Bieganowski A., 2018. Methanotrophs are favored under hypoxia in ammoniumfertilized soils. Biol. Fertil. Soils, 54, 861-870, https://doi. org/10.1007/s00374-018-1302-9.

Wnuk E., Walkiewicz A., and Bieganowski A., 2017. Methane oxidation in lead-contaminated mineral soils under different moisture levels. Environ. Sci. Pollut. Res., 24, 25346-25354, https://doi.org/10.1007/s11356-017-0195-8.

Yang S. and Chang H., 1998. Effect of environmental conditions on methane production and emission from paddy soil. Agric. Ecosyst. Environ., 69, 69-80, https://doi.org/10.1016/ S0167-8809(98)00098-X

Zeng L.S., Liao M., Chen C.L., and Huang C.Y., 2006. Effects of lead contamination on soil enzymatic activities, microbial biomass and rice physiological indices in soil-lead-rice (Oryza sativa L.) system. Chemosphere, 65, 567-574. doi: 10.1016/j.ecoenv.2006.05.001 